\title{
SELECTION OF FAT AND VEGETABLE COMPONENTS FOR THE PRODUCTION OF COMBINED ICE CREAM
}

\author{
L. Lanzhenko, Candidate of Technical Sciences, docent \\ ORCID ID: 0000-0002-6123-6047 \\ N. Dets, Candidate of Technical Sciences, docent \\ ORCID ID: 0000-0003-4524-7560 \\ 0. Kruchek, Candidate of Technical Sciences, docent \\ ORCID ID: 0000-0002-8858-3081
}

Ye. Izbash, Candidate of Technical Sciences, docent

ORCID ID: 0000-0002-6186-7519

Department of dairy, oil-fat products and cosmetics, Odessa National Academy Of Food Technology

The article substantiates the prescription composition of combined ice cream using vegetable oils and basil extract. There were carried out research of the process of extraction of biologically active substances from dry basil leaves and mathematical modeling for a balanced fatty acid composition of the finished target product.

The quality indicators of vegetable oils and milk basil extract are determined. There were obtained satisfactory results of the use of milk extract, sunflower and sesame oils as raw materials for the production of ice cream.

Keywords: combined ice cream, vegetable oils, balanced fatty acid composition, basil, extraction, polyphenolic compounds.

Preamble. The rapid development of the world and domestic food industry causes the expansion of the range of dairy products by creating innovative technologies of natural and enriched products. This trend leads to an increase in demand for dairy products enriched with natural components which contain biologically active substances (BAS) of natural origin, which exhibit technological functionality and they are recognized micronutrients. Exactly for such recipe components can be attributed herbal extracts and oils [1, p. 95].

The scientific approach to the creation of new combined dairy products which in their nutritional value correspond to the physiological norms of different population groups sets the intensive development of studies united by the concept of «food design» [2, p. 78]. In the designing of such products, particulary combined ice cream, milk is often combined with vegetable origin raw materials rich of:

- prebiotics, dietary fiber, BAS (polyphenolic compounds, antioxidants);

- complete proteins of vegetable origin;

- essential polyunsaturated fatty acids (PUFA) (sunflower, linseed, rice, sesame, raspberry, grape and other types of oils) [2, p. 78].
Relevance. Most of the modern commodity market is occupied by fast-frozen food products, in particular ice cream, whose production and consumption is increasing every year in Ukraine and throughout the world. [3, p.173].

Trends of recent years dictate the creation of new types of functional and special-purpose products with using both of fat and vegetable components in dairy products. The popularity of healthy lifestyles defines several areas of current market trends: naturalness of the product and careful analysis of raw ingredients. In the field of ice cream production, the most popular was the easy-to-use target product of simple recipe without synthetic additives, dyes, artificial flavors. There are more and more ice creams appear which are positioned as a component of a healthy diet. Manufacturers are expanding the range of ice cream with various functional additives (vitaminized ice cream, iodized, high calcium, probiotic additives, bio-ice cream), as well as with reduced fat and sugar content [4, p.53; 5, p.106; 6, p.123].

An unbalanced diet is one of the main risk factors for many diseases that can be prevented by the systematic consumption of a wide range of products with wellness properties, including the use of vegetable oils and vegetable components (including spices) to maintain health [7, p. 175]. 
When using fat components in the composition of functional foods, they are subject to requirements, in particular subject to the ratio of saturated (SFA), monounsaturated (MUFA) and polyunsaturated (PUFA) fatty acids, which should be $1,0: 1,0: 1,0$. In milk fat, this ratio averages $0,63: 0,32: 0,06$. For approaching the fatty acid composition of milk fat to the recommended norms of nutrition, it is necessary to carry out its normalization with vegetable oils (in particular, sunflower and sesame), containing a significant amount of PUFA and not containing cholesterol [8, p. 993].

Vegetable oils are an important part of a human's diet. They are sources of essential fatty acids, which in turn are precursors to important hormones that control many physiological processes [9, p. 1497]. Sunflower oil contains high levels of PUFA (linoleic and linolenic) and low levels of PUFA (myristic, palmitic and stearic) $[10$, p. 232]. Sesame oil is characterized by high levels of tocopherols, sesamolin, $\omega-6$ fatty acids, which causes its health effect, anti-inflammatory effects and antiproliferative activity on cancer cells [11, p. 107].

More and more often vegetable components are used in products as a source of antioxidants for preserving both products and consumer's health. Many herbal spices have high antioxidant activity. Basil (Ocimum basilicum) - aromatic and medicinal herb, which has various therapeutic effects, contains ascorbic acid (in dried $-61 \mathrm{mg} / 100 \mathrm{~g}$ ); phenolic compounds (carotenoids, catechins, flavonol glycosites, etc.), which act as potent antioxidants and «scavengers» of free radicals; tannins 23,6\%; essential oils of $4,8 \%$, namely eugenol, demonstrating bactericidal properties; organic acids of $0,5 \%$. [12, p. 302; 13, p. 35].

In view of the above, it is advisable to produce a new type of combined ice cream with adding of vegetable components.

Analysis of recent research. In recent years, the world market of new technologies and food products has been replenished with qualitatively new products designed to prevent various diseases, strengthen the body's defenses, reduce the risk of exposure to toxic compounds and adverse economic factors. In addition, there is increasing interest in the creation of combined types of ice cream based on liquid vegetable oils [14, p.204; 15, p.2521].

Demand for low-calorie or balanced fatty acid products is increasing in the world and in Ukraine. Although ice cream remains one of the most favorite desserts, it contains a high level of unbalanced SFA : MUFA : PUFA milk fat [16, p.137].

In addition, vegetable components, which are increasingly being added to dairy products (in particular, in ice cream), contain compounds with $\mathrm{P}$ vitamin activity that absorb metal chelators, minimizing oxidative damage to the body. Therefore, an emulsion for ice cream production may consist of dairy products, water, vegetable oils, sugars, stabilizers, vegetable ingredients which provide the nutritional value of the targeted product [17, p. 183].

Therefore, the authors selected fat and vegetable components for the production of combination ice cream with a balanced fatty acid composition of special purpose.

The purpose of the work was to select the components for the preparation of a fatty acid composition of the lactic-fat mixture and to develop the parameters of basil extraction to obtain a basilic extract enriched with phenolic compounds for the preparation of special-purpose ice cream.

To achieve this purpose the following tasks were solved:

- to determine the organoleptic and physicochemical parameters of vegetable oils;

- to prove the expediency of using vegetable oils that would meet the requirements of an approximate «ideal» fatty acid composition and to perform mathematical modeling of the fatty acid composition of the lactic-fat base;

- to substantiate the rational technological parameters of basil extraction and to determine the quality of the finished extract for its use in diary products with the addition of plant components.

Materials and methods of research. For the experimental research whole cow's milk was used as basic raw material according to DSTU 3662:2018, skimmed milk obtained by separating whole milk of not less than 1 st grade, acidity not higher than $19^{\circ} \mathrm{T}$, density not lower than $1030 \mathrm{~kg} / \mathrm{m} 3$; distilled water; sesame oil - according to TU U 10.4-386673350001:2013, sunflower oil - DSTU 4492:2005, dry basil according to DSTU 2175-93.

Acid, peroxide and iodine numbers of vegetable oils were determined according to DSTU ISO 5555:2003; mathematical modeling of the fatty acid composition of lactic-fat mixture for the production of combined ice cream was performed on the basis of the mathematical model proposed by prof. N.N. Lipatov [18, p. 120]; the mass fraction of phenolic compounds was determined by spectrophotometric method with Folin-Ciocalteu reagent [19, p. 170]; mass fraction of solids - by the arbitration method according to DSTU ISO 6731:2007; the titrated acidity of the samples was determined by the titrimetric method according to GOST 3624-92; active acidity - by potentiometric method according to DSTU 8550:2015; temperature - according to DSTU 6066:2008; count of bacterial group of Escherichia coli (BGEC) - according to DSTU IDF 73A:2003.

Results of the research and their discussion. Oils have been selected for scientific research: 
sunflower - as unique and most popular among consumers; flax - as a source of omega -3 fatty acids; grape - as a universal product with a high content of biologically active substances.

The first stage of the experimental research consisted of the selection of vegetable oils among sunflower, linseed, grape, cherry, apricot, sesame according to the literary data of the fatty acid composition and conducted physicochemical and organoleptic researches.

After analyzing the fatty acid composition of the selected vegetable and stone oils, their organoleptic characteristics (taste, smell, color and transparency) were determined. The results of organoleptic evaluation of vegetable oils are given in table 1.

Table 1

The results of organoleptic evaluation of vegetable oils

\begin{tabular}{|l|c|c|c|c|}
\hline \multicolumn{1}{|c|}{ Oils } & Smell & Taste & Colour & Transparency \\
\hline Cherry & Cherry & Cherry bones & Dark-yellow with a green tint & $\begin{array}{c}\text { The emulsion, not transparent, } \\
\text { is cloudy }\end{array}$ \\
\hline Grape & Grapevine & Oil taste & Green-brown & Transparent \\
\hline Apricot & Apricot with nutmeg & Apricot bones & Yellow & Not transparent, there is a grid \\
\hline Sesame & Sesame oil, oil taste & Sesame seeds & Yellow- green tint & Transparent \\
\hline Sunflower & Fresh bones & Pleasant & Yellow & Transparent \\
\hline Linseed & Herbal & The taste linseed & Rich orang & Transparent \\
\hline
\end{tabular}

The results of the organoleptic evaluation (table 1) do not allow the use of cherry oil, as transparency studies have shown the presence of turbidity and sediment.
The next stage was devoted to the determination of acid, peroxide and iodine numbers of selected oils, the results are presented in table 2.

Table 2

The results of acid, peroxide and iodine numbers of vegetable oils

\begin{tabular}{|l|c|c|c|c|c|}
\hline \multicolumn{1}{|c|}{ Oils } & $\begin{array}{c}\text { Acid numbers, } \\
\mathrm{mg} \mathrm{NaOH} / \mathrm{g}\end{array}$ & $\begin{array}{c}\text { Oil grade by acid } \\
\text { numbers }\end{array}$ & $\begin{array}{c}\text { Peroxide } \\
\text { numbers, } \% \mathrm{~J}_{2}\end{array}$ & $\begin{array}{c}\text { Iodine number, } \\
\mathrm{g} / 100 \mathrm{~g}\end{array}$ & $\begin{array}{c}\text { The degree of damage to } \\
\text { fat by iodine number }\end{array}$ \\
\hline Cherry & 4,0 & 2nd & 0,0010 & 94 & Fresh \\
\hline Grape & 2,8 & $1 \mathrm{st}$ & 0,0127 & 103 & Fresh \\
\hline Apricot & 0,46 & Higher & 0,0630 & 93 & $\begin{array}{c}\text { Not fresh, is not to be } \\
\text { stored }\end{array}$ \\
\hline Linseed & 2,7 & $1 \mathrm{st}$ & 0,0045 & 110 & Fresh \\
\hline Sunflower & 1,3 & Higher & 0,0050 & 110 & Fresh \\
\hline Sesame & 2,6 & $1 \mathrm{st}$ & 0,0045 & 112 & Fresh \\
\hline
\end{tabular}

The data obtained by acid number (Table 2) indicates the freshness of grape, apricot, linseed, sunflower, sesame oils. The value of the acid number for cherry oils $(4,0 \mathrm{mg} \mathrm{NaOH} / \mathrm{g})$ corresponds to the second grade of oil, which correlates accordingly with the organoleptic evaluation data obtained. Vegetable oils not lower than 1st grade by acid number are allowed for consumption.

The obtained data indicates the freshness of the peroxide number of all selected vegetable and stone oils. The peroxide number is in the range $0,0010 \ldots 0,630 \% \mathrm{~J}_{2}$.

The obtained data of the study of iodine number correlates with the literature data: iodine number of sunflower oil according to the literary data is 109 $120 \mathrm{~g} / 100 \mathrm{~g}$ (according to studies - $110 \mathrm{~g} / 100 \mathrm{~g}$ ); sesame oil - 103-117 g/100 g (according to studies $112 \mathrm{~g} / 100 \mathrm{~g})$.
The next stage of experimental research was mathematical modeling of milk-fat basis for the production of combined ice cream. The standard was the ratio of SFA : MUFA : PUFA 1,0:1,0: 1,0, which characterizes the ideal fat. Based on the mathematical model proposed by prof. N.N. Lipatov, simulated fatty acid composition in the program Excel. The following fatty acid composition of sunflower, sesame oils and milk fat were used in the simulation: 7,6\% SFA, 32,0\% MUFA, 60,4\% PUFA (for sunflower oil); $13,6 \%$ SFA, 27,0\% MUFA, 42,5\% PUFA (for sesame oil); 62,9\% SFA, 30,9\% MUFA, $6,2 \%$ PUFA (for milk fat).

Based on the obtained data, a quantitative ratio of sunflower, sesame oils and milk fat was created (Table 3). 
Table 3

The mathematical modeling of fatty acid composition

\begin{tabular}{|c|c|c|c|c|c|c|c|c|}
\hline $\begin{array}{c}\text { Sunflower } \\
\text { oil }\end{array}$ & Sesame oil & Milk fat & SFA & MUFA & PUFA & SFA : & MUFA : & PUFA \\
\hline 0 & 0 & 1 & 62,9 & 30,9 & 6,20 & 10,1 & 5,0 & 1,0 \\
\hline 0,05 & 0 & 0,95 & 60,14 & 30,96 & 8,91 & 6,7 & 3,5 & 1,0 \\
\hline 0 & 0,05 & 0,95 & 60,44 & 30,71 & 8,02 & 7,5 & 3,8 & 1,0 \\
\hline 0,05 & 0,05 & 0,9 & 57,67 & 30,76 & 10,73 & 5,4 & 2,9 & 1,0 \\
\hline 0,05 & 0,1 & 0,85 & 55,21 & 30,57 & 12,54 & 4,4 & 2,4 & 1,0 \\
\hline 0,1 & 0,05 & 0,85 & 54,91 & 30,82 & 13,44 & 4,1 & 2,3 & 1,0 \\
\hline 0,1 & 0,1 & 0,8 & 52,44 & 30,62 & 15,25 & 3,4 & 2,0 & 1,0 \\
\hline 0,15 & 0,1 & 0,75 & 49,68 & 30,68 & 17,96 & 2,8 & 1,7 & 1,0 \\
\hline 0,1 & 0,15 & 0,75 & 49,98 & 30,43 & 17,07 & 2,9 & 1,8 & 1,0 \\
\hline 0,15 & 0,15 & 0,7 & 47,21 & 30,48 & 19,78 & 2,4 & 1,5 & 1,0 \\
\hline 0,2 & 0,15 & 0,65 & 44,45 & 30,54 & 22,49 & 2,0 & 1,4 & 1,0 \\
\hline 0,15 & 0,2 & 0,65 & 44,75 & 30,29 & 21,59 & 2,1 & 1,4 & 1,0 \\
\hline 0,2 & 0,2 & 0,6 & 41,98 & 30,34 & 24,30 & 1,7 & 1,2 & 1,0 \\
\hline 0,2 & 0,22 & 0,58 & 40,99 & 30,26 & 25,03 & 1,6 & 1,2 & 1,0 \\
\hline 0,2 & 0,25 & 0,55 & 39,52 & 30,15 & 26,12 & 1,5 & 1,2 & 1,0 \\
\hline 0,25 & 0,25 & 0,5 & 36,75 & 30,20 & 28,83 & 1,3 & 1,0 & 1,0 \\
\hline
\end{tabular}

Mathematical modeling (table 3) at the ratio of sunflower oil : sesame oil : milk fat $0,25: 0,25: 0,5$ the ratio of SFA : MUFA : PUFA $1,3: 1,0: 1,0$ is reached, which is maximum close to perfect $1,0: 1,0$ $: 1,0$.

It is recommended to use this ratio of selected fats in the recipe for the production of combined ice cream with a balanced fatty acid composition.

On the next stage of the experiment, extraction of the dried basil leaves was carried out to obtain the finished extract for further use in the recipe of combined ice cream.
The basil extract was prepared as follows: the dried leaves were purified, crushed, poured with water or skim milk; was extracted at a temperature of $40,50,60^{\circ} \mathrm{C}$ for $60 \mathrm{~min}$. Samples were collected every $15 \mathrm{~min}$. The resulting extract was filtered. The content of phenolic substances was chosen as the criteria for evaluating the efficiency of extraction. For the study used one hydromodule - the ratio of basil : extractant 1 : 10 (the amount of basil $-10 \mathrm{~g}$, the amount of extractant (water or skim milk) $100 \mathrm{~g}$ ). The dependences of the content of polyphenolic compounds on the duration of extraction are presented in Fig. 1.

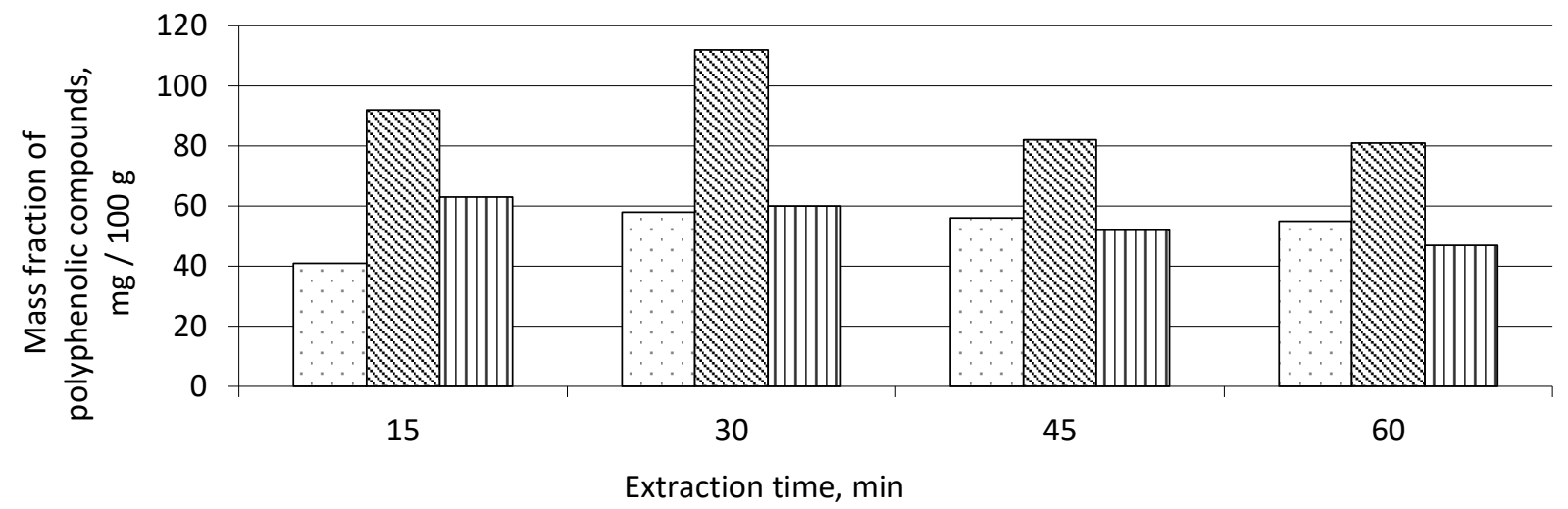

a) 


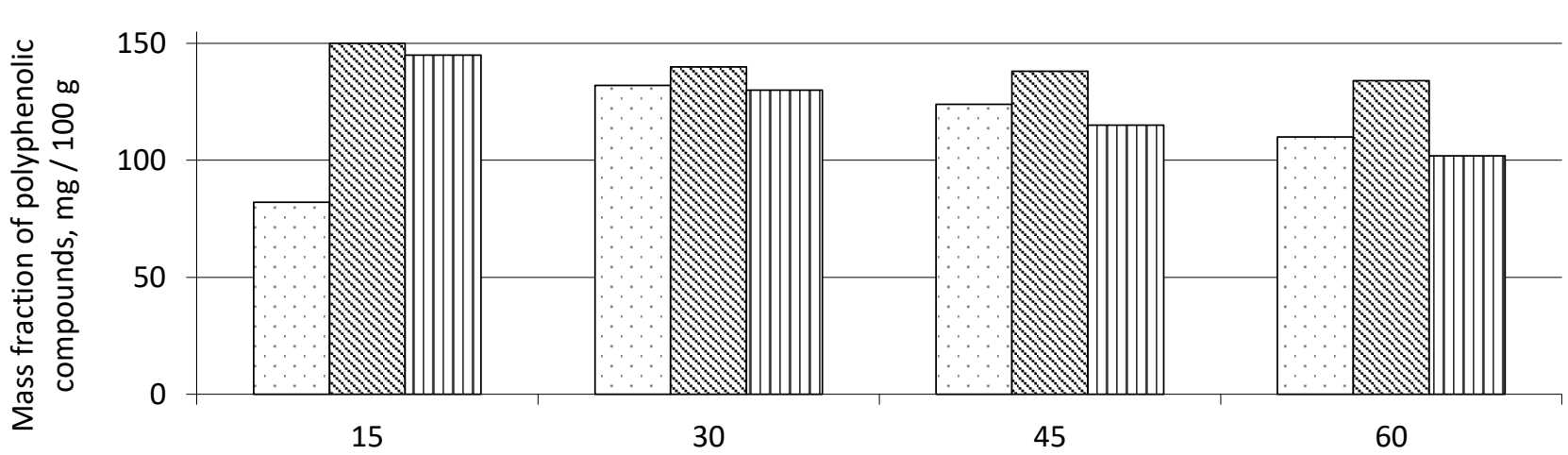

Extraction time, $\min$

b)

Fig. 1. - Dependence of extraction of phenolic compounds with water (a) and skim milk (b) from basil on duration and temperature at hydromodule $1: 10: \square-40{ }^{\circ} \mathrm{C}, \mathbb{A}-50{ }^{\circ} \mathrm{C}, \square-60^{\circ} \mathrm{C}$.

Analyzing the data obtained (Fig. 1), we can conclude that the amount of extracted BAS is significantly influenced by temperature and extractant. The data obtained indicate that the amount of polyphenolic compounds in the extraction of basil skim milk is 1,6 times greater than when extracted with water. The maximum amount of extracted phenolic substances was observed after $15 \mathrm{~min}$ extraction at a temperature of $50^{\circ} \mathrm{C}$ and the ratio of extractant : leaves Ocimum basilicum 10 : 1, with $150 \mathrm{mg} / 100 \mathrm{~g}$ of phenolic compounds when used as an extract of skim milk.

Prolonged effect of temperature adversely affects on the extract's content of polyphenolic compounds therein and their mass fraction after $15 \mathrm{~min}$ of extraction begins to decrease.

At the end of water extraction (after $60 \mathrm{~min}$ ) the mass fraction of phenolic compounds in the extracts was respectively $55,81,47 \mathrm{mg} / 100 \mathrm{~g}$ at the corresponding temperatures of 40,50 and $60^{\circ} \mathrm{C}$.
After 60 min extraction of basil leaves with skim milk mass fraction was $110,134,102 \mathrm{mg} / 100 \mathrm{~g}$, respectively, at similar temperatures of $40,50,60^{\circ} \mathrm{C}$.

When extracting basil with water, the maximum mass fraction of phenolic substances at a similar ratio of "extractant : the basil" is reached at a temperature of $50^{\circ} \mathrm{C}$ after 30 minutes and was $112 \mathrm{mg}: 100 \mathrm{~g}$ of extract.

Analysis of data results shows that the rational parameters of basil polyphenolic compounds' extraction are "extractant - skim milk" at temperature $50^{\circ} \mathrm{C}$, with duration 15 minutes and at the ratio of "extractant : leaves of basil" as $10: 1$.

In the finished milk basil extract there was determined organoleptic (taste, flavor, color, consistency), physicochemical (mass fraction of dry substances and mass fraction of polyphenolic compounds) and microbiological (number of bacteria of the group of Escherichia coli) indicators (table 4).

Table 4

Quality indicators of basil milk extract

\begin{tabular}{|l|l|}
\hline \multicolumn{1}{|c|}{ The name of indicator } & \multicolumn{1}{c|}{ The value of indicator } \\
\hline Mass fraction of dry substances, $\%$ & $15 \pm 1$ \\
\hline Mass fraction of polyphenolic compounds, $\mathrm{mg} / 100 \mathrm{~g}$ & $150 \pm 2$ \\
\hline Taste and smell & Tart, with a taste of basil, the aroma of milk, basil \\
\hline Color & Milk-brown, similar to cocoa with milk or crème-brulee \\
\hline Consistency & Liquid, homogeneous throughout, without sediment \\
\hline $\begin{array}{l}\text { Quantity of bacteria of the group of Escherichia coli, in } \\
0,1 \mathrm{~g} \text { of the product }\end{array}$ & Are absent \\
\hline
\end{tabular}

According to obtained quality indicators, the finished milk basil extract contains a sufficient amount of biologically active substances, which allows to be used as a raw material component in the receipts of new types of special-purpose products, including combined ice cream using vegetable components.
Conclusions and prospects of use. Based on the generalization of theoretical and experimental researches:

1. The fatty acid composition was analyzed and the physicochemical and organoleptic parameters of vegetable and stone oils were investigated - as a result of which sunflower and sesame seeds were 
selected for modeling of the fatty acid composition of the milk-fat mixture as raw material for the production of special-purpose combined ice cream.

2 . The mathematical modeling of the fatty acid composition of the lactic-fat component was carried out - as a result, at the ratio of sunflower oil, sesame oil and milk fat $0,25: 0,25: 0,5$, the maximum approximation to the ideal ratio of SFA : MUFA : PUFA is achieved $1,3: 1,0: 1,0$.
3. There were obtained rational parameters of the process of extraction of biologically active substances of the basil $-50^{\circ} \mathrm{C}$ for 15 minutes, the extractant is skim milk, the ratio of "basil leaves : extractant" is 1 : 10 as at these parameters the maximum value of phenolic compounds in the extract is reached $150 \mathrm{mg} / 100 \mathrm{~g}$.

4. Results of quality indicators of finished basil extract's researches allows to use it as a raw material ingredient in the production of combined ice cream.

\section{Список використаних джерел:}

1. Поліщук Г.Є. та ін. Мікробіологічні показники рослинних екстрактів для виробництва морозива. Біотехнологія. 2011 . Т. 4, № 4. C. $95-100$

2. Ткаченко Н.А. та ін. Нові комбіновані продукти з радіопротекторними властивостями і збалансованим хімічним складом для військовослужбовців: перспективи виробництва. Наукові праці ОНАХТ. 2017, Т. 81, Вип. 2. С. 76-86.

3. Павлишин М.Л., Захарчин М.Р., Бурак Є.І. Формування якості морозива з додаванням дикорослих ягід. Науковий вісник НЛтУ України. 2014. Вип. 24.2. С. 173-177.

4. Ланженко Л.О. та ін. Переробка сироватки в десертні желейні продукти. Вчені записки ТнУ імені В.І. Вернадського. Серія: технічні науки. 2018. Т. 29 (68), Ч. 3, № 1. С. 53-60.

5. Дітріх І., Литвин Я. Айва японська як інгредієнт плодово-ягідного морозива. Товари і ринки. 2015. №1. С. $106-112$.

6. Павлюк Р.Ю., Погарська В.В., Берестова А.А. Інноваційні технології вітамінного плодовоягідного морозива з використанням заморожених дрібнодисперсних добавок з рослинної сировини. Восточно-Европейский журнал передовых технологий. 2013. № 4/10 (64). С. 57-62.

7. Тележенко Л., Кашкано М. Технологія горіхових соусів зі збалансованим жирнокислотним складом. Товари і ринки. 2014. № 1. C. $175-184$.

8. Medeiros E. at al. Fatty acid profile of cheese from dairy goats fed a diet enriched with castor, sesame and faveleira vegetable oils. Molecules. 2014. № 19. P. 992-1003. DOI:10.3390/molecules19010992

9. Rafiee Z. at al. Antioxidant effect of microwave-assisted extracts of olive leaves on sunflower oil. Journal of Agricultural Science and Technology. 2012. Vol. 14. P. 1497-1509.

10. Gagan Rani at al. Biochemical assay to evaluate phytoconstituents and free radical scavenging activity of sunflower (Helianthus annus L.). The Pharma Innovation Journal. 2018. № 7(3). P. 232-237.

11. Hashempour-Baltork F. at al. Chemical, rheological and nutritional characteristics of sesame and olive oils blended with linseed oil. Advanced Pharmaceutical Bulletin. 2018. № 8(1). P. 107-113. DOI: 10.15171/apb.2018.013 http://apb.tbzmed.ac.ir

12. Abbas Hayam Mohamed at al. Antioxidant, rheological and sensorial properties of ultra-filtrated soft cheese supplemented with basil essential oil. International Journal of Dairy Science. 2017. V. 12 (5). P. 301-309. DOI: 10.3923/ijds.2017.301.309.

13. Єгоров Б.В., Могилянська Н.О. Оцінка санітарних показників пряно-ароматичної сировини та пряно-олійних сумішей. Харчова наука і технологія. 2014. № 2(27). С. 34-38.

14. Сімахіна Г.О., Науменко Н.В. Харчування як основний чинник збереження стану здоров'я населення. Проблемы старения и долголетия. 2016. 25, № 2. С. 204-214.

15. Merete B. Munk at al. Using Ethylcellulose to Structure Oil Droplets in Ice Cream Made with High Oleic Sunflower Oil. Journal of Food Science. 2018. Vol.83, Iss.10. P. 2520-2527.

16. Khan Sh. at al. Sucralose and maltodextrin - an altrernative to low fat sugar free ice-cream. Bioscience biotechnology research communications. 2018. № 11(1). P. 136-143.

17. Ana Carolina Pelaes Vital at al. Ice cream supplemented with grape juice residue as a source of antioxidants. International Journal of Dairy Technology. 2018. Vol. 71, № 1. P. 183-189. DOI: 10.1111/1471-0307.12412.

18. Lanzhenko L.O, Ivashchenko A.A, Manukyan V.O. Balanced pupped oils for food and cosmetic products. Збірник наукових праць молодих учених, аспірантів та студентів ОНАХT. 2018. С. 119-121.

19. Singleton V.L., Orthofer R., Lamuela-Raventos R.M. Analysis of total phenols and other oxidations substractes and antioxidans by means of Folin-Ciocalteu reagent. Methods enzymology. 1999. № 299. P. 152-178.

\section{Л. О. Ланженко, Н. О. Дец, О. А. Кручек, Є. О. Ізбаш. Вибір жирових і рослинних компонентів для виробництва комбінованого морозива}

У роботі обгрунтовано рецептурний склад комбінованого морозива з додаванням рослинних олій $i$ базилікового екстракту. Проведено дослідження процесу екстрагування БАР з сухого листя базиліку та математичне моделювання для збалансованого жирно-кислотного складу готового цільового продукту.

Визначено показники якості рослинних олій та молочного базилікового екстракту. Отримано задовільні результати з використання молочного екстракту, соняшникової і кунжутної олій у якості сировинних компонентів для виробництва морозива. 
Ключові слова: комбіноване морозиво, рослинні олії, жирно-кислотний склад, базилік, екстрагування, поліфенольні сполуки.

\section{Л. А. Ланженко, $\quad$ Н. А. Дец, $\quad$ О.А. Кручек, $\quad$ Е. А. Избаш. Выбор жировых и растительных компонентов для производства комбинированного мороженого}

В работе обоснован рецептурный состав комбинированного мороженого с использованием растительных масел и базиликового экстракта. Проведены исследования процесса экстрагирования БАВ из сухих листьев базилика и математическое моделирование для сбалансированного жирнокислотного состава готового целевого продукта.

Определены показатели качества растительных масел и молочного базиликового экстракта. Получены удовлетворительные результаты по использованию молочного экстракта, подсолнечного и кунжутного масел в качестве сырьевых компонентов для производства мороженого.

Ключевые слова: комбинированное мороженое, растительные масла, жирно-кислотный состав, базилик, экстрагирование, полифенольные соединения. 